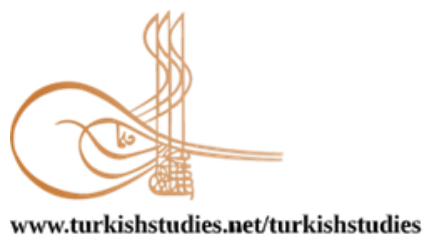

Turkish Studies

www.turkishstudies.net/turkishstudies

eISSN: $1308-2140$

BALKAN
UNTVERSTIY

Sponsored by IBU

Research Article / Araștırma Makalesi

\title{
COVID-19 Pandemi Sürecinde Sağlık Çalışanlarında Maske Kullanımının Etkilerinin Değerlendirilmesi
}

\author{
Evaluation of the Effects of Wearing Masks among Healthcare Professionals During COVID-19 \\ pandemic
}

\author{
Çağdaş Biçen* - Emre Ertürk**
}

\begin{abstract}
The aim of this study is to evaluate different types of masks and difficulties that are observed while wearing masks during the COVID-19 pandemic. The study was performed following local ethical committee approval. A total of 112 volunteers, 78 females and 34 males, working at Izmir University of Economics Medical Park Hospital, consisting of secretaries, nurses and doctors, were included in the study. Volunteers were divided into two groups as those using surgical medical masks and FFP2 masks. 81 volunteers using surgical medical masks were included in the first group and 31 volunteers using FFP2 mask were included in the second group. Development of dyspnea, vision disturbance, ear pain, headache, discomfort on face and anxiety complaints during the 60th and 180th minutes during mask usage was questioned. In addition, changes of oxygen saturation and changes of heart beat rate were measured with the pulse oximeter at 60th and 180th minutes and compared with the baseline values. Variation of the complaints were evaluated regarding allergy, smoking and use of glasses. For statistical analysis, the statistical package SPSS version 17 was used. The distribution of the data was analyzed with Kruskal Wallis and Shapiro Wilk tests. The data was found to be normally distributed. The difference between the groups in terms of oxygen saturation and heart beat rates in 60th and 180th minutes was compared with baseline values using Student-t test. A p value of $<0.05$ was considered statistically significant. The Chi-square test was used to determine the difference in dyspnea, anxiety, discomfort on face, headache, pain in the ear, and visual disturbance. In both groups; when compared to baseline values, difference in oxygen saturations in 60th minutes $(\mathrm{p}<0.001)$ and 180th minutes $(\mathrm{p}<0.001)$ were found to be statistically significant. Statistically significant difference was also found in heart beat rate, in comparison between baseline values and values in 60th minutes $(\mathrm{p}<0.001)$ and 180th minutes $(\mathrm{p}<0.001)$. There was no statistically significant difference between the changes of oxygen saturation values in 180th minutes and the mask type, the presence of allergy, the use of glasses, smoking, age and gender. As a result, it has been observed that the FFP2 type masks are more difficult to tolerate in use. Although, both types of masks showed a decrease in oxygen saturation and heart beat rate after 180 minutes of use, these values remained within physiological limits. During the COVID-19 pandemic, as an important barrier for protection of
\end{abstract}

\footnotetext{
* Dr. Öğr. Üyesi, İzmir Ekonomi Üniversitesi Medical Park Hastanesi, Ortopedi ve Travmatoloji Bölümü Asst. Prof. Dr., Izmir University of Economics Medical Park Hospital, Department of Orthopedics and Traumatology ORCID 0000-0002-0711-9376

cagdasbicen@hotmail.com

** Dr. Öğr. Üyesi, İzmir Ekonomi Üniversitesi Medical Park Hastanesi, Kardiyoloji Bölümü

Asst. Prof. Dr., Izmir University of Economics Medical Park Hospital, Department of Cardiology

ORCID 0000-0002-6191-4493

emerturk@gmail.com

Cite as/ Atıf: Biçen, Ç. \& Ertürk, E. (2020). COVID-19 Pandemi sürecinde sağlık çalışanlarında maske kullanımının etkilerinin değerlendirilmesi. Turkish Studies, 15(6), 205-218. https://dx.doi.org/10.7827/TurkishStudies.44128

Received/Geliș: 09 June/Haziran 2020

Accepted/Kabul: 15 October/Ekim 2020

Copyright $(\mathrm{C}$ MDE, Turkey
} 
healthcare professionals and the people in the community, on wearing masks, adverse effect has not been determined.

\section{Structured Abstract: Purpose}

COVID-19, which is caused by SARS-CoV-2 virus, was first seen in China in December 2019. The disease had clinically proven symptoms of cough, sore throat, fever; upper and lower respiratory tract infections. Although spontaneous recovery is observed in a significant number of patients, in a group of patients, disease can progress severe and fatal, with pulmonary edema, pneumonia, acute respiratory distress syndrome, multiple organ failure, and septic shock (Chen vd., 2020:507-513; Chan vd.,2020). Among the measures, the use of masks in the community was not clear in the early stages of the disease due to the risk of lacking of masks for healthcare workers. However, it is now recommended as a support for existing measures, in order to prevent droplets that can be spread through coughing or sneezing and help the social isolation (Cheng vd.,2020). Wearing masks has become widespread in the society. Headache, discomfort on face, ear pain, vision problems and dyspnea are among the frequently mentioned complaints due to mask wearing. As a small sample of population, in healthcare profesionals in our hospital we questioned existence of subjective complaints and measured vital signs. In our study, we wanted to evaluate the problems related to the use of different mask types.

\section{Method}

During the COVID-19 pandemic, 112 volunteers who used masks regularly in our hospital in September.2020 were included in the study. Volunteers consisted of secretaries, nurses and doctors working in our hospital. Volunteers were divided into two groups as those using surgical medical masks and FFP2 masks. Those using surgical medical masks were defined as the first group and those using FFP2 were defined as the second group. There were $81(72.3 \%)$ volunteers in group $1,31(27.7 \%)$ in group 2 . It is believed that the use of glasses, can facilitate headache-like symptoms when wearing masks. In the presence of smoking and allergic disease, it is believed that there may be adverse respiratory symptoms or changes in oxygen saturation values with the use of a mask. Oxygen saturations and heart beat rates of the volunteers were measured by finger pulse oximeter before wearing mask. At this stage, volunteers who reported headaches, ear pain, discomfort on face and dyspnea were excluded from the study. After wearing a mask, volunteers continued their routine work. While wearing masks, oxygen saturation (SO2) and heart beat rates were recorded in 60th minutes with pulse oximeter. At this stage, it was questioned and noted whether the volunteers experienced dyspnea, anxiety, discomfort on face, headache, pain in the ear or vision problems. In 180th minute of mask wearing, the measurements were repeated and the complaints of volunteers were questioned again. Volunteers, whose measurements could not be repeated in 60th or 180th minutes were excluded from the study.

\section{Statistical analysis}

For statistical analysis, the statistical package SPSS version 17 was used. Subjects were divided into two groups as those wearing FFP2 and those wearing traditional surgical masks. The distribution analysis of the obtained data were analyzed with Kruskall Wallis and Shapiro Wilk tests. The data were seen as distributing normally, and the mean \pm standard deviation was compared to the Student-t test; whether there was a difference between the groups using FFP2 and surgical masks in terms of oxygen saturation and pulse values in the beginning, 60th and 180th minutes. In addition, the difference in terms of oxygen saturation and pulse values in the beginning, 60th and 180th minutes within each group was evaluated by Student- $t$ test. A p value of $<0.05$ was considered statistically significant. The chi-square test was used to determine whether there was a difference in terms of dyspnea, anxiety, discomfort on face, headache, pain in the ear, and visual disturbance between and within groups. The difference between the initial values of oxygen saturation and hearth beat rate and those in 180th minute was compared with Student $t$ test as averages in terms of smoking, allergic disease history and the use of glasses. In order to determine the independent variables in terms of saturation and pulse difference, linear regression analysis was performed.

\section{Results}

In both groups, the differenece of oxygen saturation values and heart beat rates were found statistically significant, in comparison with baseline in 60th minutes $(\mathrm{p}<0.001)$ and 180th minutes $(\mathrm{p}<0.001)$. There was no statistically significant relationship among the difference of the 180th minute saturation value and the mask type, the presence of allergy, using glasses, smoking, age and gender. We observed that the FFP2 type mask is 
more difficult to tolerate in use. Although both types of masks showed a decrease in oxygen saturation and heart rate after 180 minutes of use, these values remained within physiological limits.

\section{Conclusion}

During pandemic; wearing mask is recommended for the public as well as healthcare professionals; as an additional measure to hand washing and social distance. It is not clear yet which mask to choose for daily use in the community. FFP masks are widely used in the community. However, these masks are not suitable for the society and difficult to tolerate. Wearing a surgical medical mask is sufficient. Statements have been made by some non-medical and non-scientific groups that wearing masks is harmful to health. In our study; although a considerable number of complaints have been stated in one and three hours of use, we have not found any evidence that the respiratory and circulatory system is pathologically affected. After all, we concluded that the use of a surgical medical mask in the community will help people protect themselves, and the use of masks is not harmful to health. During the COVID-19 pandemic, masks are believed as important barriers for the protection of healthcare professionals and the community.

Keywords: COVID-19, pandemic, surgical mask, FFP2, N95

Öz: Bu çalışmanın amacı COVID-19 pandemisi sürecinde farklı maske tiplerinin ve bunların kullanım güçlüklerinin incelenmesidir. Çalışma etik kurul onayı sonrası düzenlendi. İzmir Ekonomi Üniversitesi Medical Park Hastanesi'nde çalışan, sekreter, hemşire ve doktorlardan oluşan, yaş ortalaması 29,5 olan 78 kadın, 34 erkek toplam 112 gönüllü çalışmaya dâhil edildi. Gönüllüler cerrahi tıbbi maske ve FFP2 maske kullananlar olarak iki gruba ayrıldı. 1. gruba cerrahi tıbbi maske kullanan 81 gönüllü, 2. gruba FFP2 maske kullanan 31 gönüllü dahil edildi. Gönüllülerin, maske kullanımı esnasında 60. dakika ve 180. dakikada nefes darlığı, görme sıkıntısı, kulak ağrısı, baş ağrısı, yüzde rahatsızlık hissi, anksiyete şikâyetlerinin gelişip gelişmediği sorgulandı. Ayrıca 60. ve 180. dakikalarda pulse oksimetre cihazı ile gönüllülerin oksijen satürasyonları ve kalp atım sayılarındaki değişiklik ölçüldü ve başlangıç değerleriyle kıyaslandı. Şikâyetlerin; alerji, sigara kullanımı ve gözlük kullanımı ile değişkenlik gösterip göstermediği değerlendirildi. Verilerin analizinde SPSS 17 paket program kullanıldı. Mevcut verilerin dağılımı Kruskal Wallis ve Shapiro Wilk testleri ile incelendi. Verilerin normal dağılım paterninde olduğu saptandı ve ortalama \pm standart sapma olarak, gruplar arasında başlangıç, 60 ve 180. dakika satürasyon ve nabız değerleri açısından fark olup olmadığı Student-t testi ile karşılaştırıldı. $\mathrm{p}<0.05$ istatistiksel olarak anlamlı kabul edildi. Nefes darlığı, anksiyete, yüzde rahatsızlık hissi, baş ağrısı, kulakta ağrı ve görme sıkıntısı açısından grupların kendi içinde ve gruplar arasında fark olup olmadığı Ki-Kare testi ile değerlendirildi. Her iki grupta da başlangıç ile 60 . Dakika(p<0.001) ve 180 dakika $(\mathrm{p}<0.001)$, oksijen satürasyonları açısından istatistiksel anlamlı fark bulunmuştur. Yine başlangıç nabız değerleri ile 60.dakika $(p<0.001)$ ve 180 . dakika nabız değerleri açısından $(p<0.001)$ istatistiksel anlamlı fark bulunmuştur. 180. dakika satürasyon değeri arasındaki fark ile maske türü, alerji varlığı, gözlük kullanımı, sigara kullanımı, yaş ve cinsiyet arasında istatistiksel anlamlı ilişki saptanmamıştır. FFP2 tipi maskenin cerrahi maske kullanımıyla kıyaslandığında, daha fazla şikâyete yol açtığı saptanmıştır. Sonuç olarak FFP2 tipi maskenin kullanımda tolerasyonunun daha zor olduğu görülmüsstür. Her iki maske tipinde de 180 dakika kullanım sonunda oksijen satürasyonu ve kalp atım hızında düşüş görülmesine rağmen, bu değerler fizyolojik sınırlarda kalmıştır. COVID-19 pandemisi sürecinde, sağlık çalışanları ve toplumdaki kişilerin kendilerinin korunması için önemli bir bariyer olan maske kullanımının sağlık üzerine olumsuz etkisi saptanmamıştır.

Anahtar Kelimeler: COVID-19, pandemi, cerrahi maske, FFP2, N95

\section{Giriş}

SARS-CoV-2 virüsünün etkeni olduğu COVID-19, ilk olarak Çin'de Aralık.2019'da görülmüştür (Zhu vd.,2020:727-733; Chan vd., 2020:514 -523). Hastalık klinik olarak sıklıkla öksürük, boğaz ağrısı ve ateşe yol açmakta; üst ve alt solunumu yolu enfeksiyonları şeklinde seyretmektedir (Zhou vd., 2020:270-273). Hastaların önemli bir kısmında spontan iyileşme görülmesine karşın, bir kısmında hastalık pulmoner ödem, pnömoni, akut respiratuar distres sendromu, çoklu organ yetmezliği ve septik şok gibi ağır ve ölümcül tablolarla ilerleyebilmektedir (Chen vd., 2020:507-513; Chan vd.,2020). Yüksek bulaştırıcılığa sahip hastalık Dünya Sağlık Örgütü 
(DSÖ) tarafindan 11.Mart.2020'de 21. yüzyılın 2. pandemisi olarak deklare edilmiştir (Cheng vd.,2020).

COVID-19 için bulaş mekanizması netlik kazanmasa da; hapşırma ve öksürmeyle, solunumu sekresyonlarıyla, damlacık yoluyla, direkt vücut temasıyla ve yüzey temasıyla olarak tanımlanmıştır (Cheng vd.,2020; Zhai,2020; Bartozko vd.,2020). Yakın temasın risk oluşturduğu klinik çalışmalarda ve hayvan çalışmalarında gösterilmiştir (Chan vd.,2020). Hastalığın tedavisinde antiviral ajanlar, antibiyotikler ve destek tedaviler yer almaktadır. Yüksek virülans sebebiyle hastalığın tedavisi kadar bulaş ve yayılımın önlenmesi de önem taşımaktadır. Daha önceki pandemilerden edinilen tecrübelerin de yardımıyla; yayılımın önlenmesinde alınan önlemler arasında, Revers-Transkriptaz Polimeraz Zincir Reaksiyonu (RT-PCR) testi ile vakaların tespiti, sinır kapatma, seyahat sınırlamaları, karantina uygulamaları, okulların kapatılması, uzaktan eğitime geçilmesi, evden çalışma seçeneklerine dönülmesi, zorunlu haller dışında evden çıkılmaması, el hijyeni ve sosyal izolasyon bulunmaktadır (Bakioğlu ve Çevik, 2020; Cheng vd.,2007:660-694; Cheng vd.,2012:223263; Corman vd.,2020, Zan ve Zan, 2020). Önlemler arasında toplumda maske kullanımı, sağlik çalışanları için yeterli kalmama riski nedeniyle hastalığın ilk zamanlarında çok tartışılsa da; tek başına bir önlem olarak kabul edilmemekle birlikte, mevcut önlemlere destek olarak, sosyal izolasyona katkı sağlaması ve öksürme veya hapşırma ile yayılabilecek damlacıkları engelleme işlevi nedeniyle art1k önerilmektedir (Chan ve Yuen, 2020; Feng vd., 2020:434-436; Hui vd., 2012). Koruyucu özelliği olan maskeler, belli kriterleri sağlamak koşuluyla; tıbbi cerrahi maskeler ve solunum koruyucu maskelerdir (FFP1, FFP2, FFP3) (MacIntyre vd.,2013:960-966). FFP1 maskeler aerosollerin en az \%80'ini, FFP2 maskeler en az \%95'ini ve FFP3 maskeler en az \%99'unu filtreleme özelliğine sahip maskeler olarak tanımlanmıştır (Hirschmann vd.,2020).

Sağlık çalışanlarının hangi tip maske kullanması gerektiğiyle ilgili farklı öneriler bulunmaktadır. COVID-19 tanılı hastalarla ilgilenen sağlık çalışanları için; Dünya Sağlık Örgütü (DSÖ) aerosolle bulaş ihtimali olan tıbbi girişimler dışında medikal maskeleri yeterli bulmaktayken, Avrupa Hastalık Önleme ve Kontrol Merkezi (ECDC) ve ABD Amerika Birleşik Devletleri Hastalık Kontrol ve Önleme Merkezi (CDC) FFP2 maskeleri aerosol bulaş ihtimali olmayan rutin bakımlarda dahi önermektedir (WHO, 2020; ECDC, 2020; CDC, 2020). Tibbi maskeler; esas olarak kullanan kişinin çevresini koruma işine yarar. Damlacıkların solunum yoluyla, maskeye takan kişiden etrafa yayılmasında önleyici bir bariyer olarak davranmaktadır. Nemlendiğinde etkinliğini yitirir, dört saatten uzun kullanılmaması önerilmektedir. FFP2 ve FFP3 maskeler ise; aerosol bulaş1 ihtimali olan, entübasyon, ekstübasyon, endotrakeal aspirasyon, bronkoskopi, endoskopik işlemler, diş tedavileri ve COVID-19 için sürüntü örneği alma esnasında önerilmektedir. COVID-19 pandemisi öncesi sağlık çalışanları cerrahi tıbbi maskeyi; cerrahi, endoskopi, bronkoskopi, aspirasyon, diş tedavileri gibi işlemler esnasında kullanırken, COVID-19 pandemisi sonrası birçok merkezde sağ lık çalışanları rutin olarak, günlük pratikte kendileri için ek bir koruma olarak cerrahi tıbbi maske kullanmaktadır (Leung vd., 2020).

COVID-19 pandemisi sürecinde bizim hastanemizde pratik uygulamamızda; COVID-19 dış1 hasta rutin muayene ve tedavi süreçlerinde, sağlık çalışanları tarafından cerrahi maske kullanılmaktadır. COVID-19 hastalarının tedavi ve takip süreçlerinde, aerosol bulaşı riski olan işlemlerde FFP2 ve FFP3 maskeler kullanılmaktadır. Maskeler her dört saatte bir değiştirilmekte, özellikli işlemler esnasında maskeler tek sefer kullanılmaktadır.

COVID-19 pandemisi sürecinde toplumda maske kullanımının nasıl olması gerektiği de çok tartış1lan bir konu olmuştur (Chan ve Yuen,2020). Birçok bilimsel makalede toplumda maske kullanımı, sağlık çalışanları için yeterli maske kalmayabileceği tehlikesi belirtilmekle beraber, ek bir koruyucu önlem olarak önerilmektedir (Guan vd., 2020; Sun vd., 2020). Ancak maske kullanımının SARS-CoV-2 virüsüne karşı korunmada, güçlüklerini belirten çalışmalar da mevcuttur (Ma vd., 2020). Bununla beraber toplumda maske kullanımı yaygınlaşmıştır. Maske kullanımı sonrası; baş 
ağrıs1, yüzde gerginlik hissi, kulak ağrısı, görme sorunları ve nefes darlı̆̆ı sık dile getirilen şikâyetler arasındadır (Morishima ve Kishida, 2018). Maskenin toplumda kullanımını önermeyen çevreler; bu şikâyetlerin sağllğı kötü yönde etkileyebileceği düşüncesini belirtmektedir. Ancak bu konuda bilimsel veriler sunulmamaktadır. Biz toplumda maske kullanımının; bilimsel veriler ışığında COVID-19 yayılımının önlenmesinde ve toplum sağlığının korunmasında gerekli olduğunu düşünmekteyiz. Biz, maske kullanımıyla ilgili dile getirilen şikâyetler hakkında literatürde fazla yayın olmadığını gördük. Maske kullanımındaki bu şikâyetlerin sağlığa etkilerini subjektif ve objektif kriterlerle değerlendirmek istedik. Maske kullanımıyla ilgili çalışmalar sıklıkla sağlık çalışanlarından seçilen gönüllülerle yapılmaktadır (Al Badri vd., 2017; Zuo vd., 2020). Bu tarz bir çalışmayı toplumda yapmanın; hem maske kullanım şekli ve süresinin standardizasyonu, hem de düzenleme güçlügü nedeniyle oldukça zor olacağı düşünülmüsstür. Hastanemizde COVID-19 pandemisi sürecinde, sağlık çalışanları tarafından farklı maske tipleri ECDC ve CDC'nin önerdiği şekilde kullanılmaktadır. Uygun şekilde ve uzun saatler boyunca maske kullanan hastane çalışanlarında; subjektif şikâyetlerin gelişimi ve kardiyak ve pulmoner sistemdeki ölçümlerle vücut değerlerindeki değişimini incelemek istedik. Biz çalışmamızda, bu örneklem grubunun verilerinin düzenli maske kullanımını yansıtacağı için topluma uyarlanabileceğini düşündük.

\section{Materyal ve metod}

Hastanemizde günlük pratikte sağlık çalışanlarına korumaya yönelik ek bir bariyer olarak; bilimsel çevrelerce yapılan değerlendirmeler sonrasında önerildiği şekilde, cerrahi tıbbi maske daha yaygın kullanılmaktadır. FFP2 maskeler ise sıklıkla yine öneriler doğrultusunda; endoskopi, bronkoskopi işlemleri esnasında, COVID-19 kapalı servislerinde tedavi ve bakımlar esnasında, COVID-19 izole yoğun bakım ünitesinde tedavi ve bakımlar esnasında, acil servis COVID-19 triajında ve örnek alma esnasında kullanılmaktadır.

COVID-19 Pandemisi sürecinde Eylül.2020'de hastanemizde düzenli maske kullanan 112 gönüllü çalışmaya dahil edildi. Gönüllüler hastanede çalışan sekreter, hemşire ve doktorlardan oluşmaktaydı. Gönüllüler cerrahi tıbbi maske ve FFP2 maske kullananlar olarak 2 gruba ayrild1. Servis, poliklinik ve ameliyathane çalışanları sıklıkla cerrahi maske kullanmaktaydı. Yoğun bakım çalışanları, COVID-19 servisi çalışanları ve acil servis çalışanlarında ise FFP2 kullanımı diğer alanlarda çalışanlara göre daha yaygındı. Gönüllüler pandemi sürecinde rutin pratikte düzenli maske kullanan çalışanlar arasından seçildi. Çalışmaya dahil edilmek üzere, herhangi bir kişiye belirli bir süre için maske kullandırılmadı. Kronik alt ve üst solunum yolu hastalığı olan kişiler, akut alt veya üst solunum enfeksiyonu geçirmekte olan kişiler çalışma dışı bırakıldı. Cerrahi tıbbi maske kullananlar 1. grup, FFP2 kullananlar 2. grup olarak tanımland1. 1.grupta 81(\%72,3), 2. grupta $31(\% 27,7)$ gönüllü yer almaktaydı. Gönüllülerin yaşları, cinsiyetleri, gözlük kullanımları, alerji mevcudiyeti ve sigara kullanımları not edildi (Tablo 1). Gözlük kullanımının, maske ile kullanımda, maske uyumunu zorlaştırıp, baş ağrısı benzeri semptomların oluşmasını kolaylaştırabileceği düşünülmüştür. Sigara içimi ve alerjik hastalık varlığında ise solunum yolundaki akut ve kronik değişikliklere ikincil olarak, hava akışını mekanik olarak etkileyen maske kullanımıyla farklı semptomların gelişebileceği ya da satürasyon değişikliği olabileceği düşünülmüştür.

Tablo 1: Gönüllülerin Demografik Özellikleri

\begin{tabular}{lllll}
\hline & $\begin{array}{l}\text { Cerrahi } \\
\text { maske(81) }\end{array}$ & $\begin{array}{l}\text { Standart } \\
\text { sapma }\end{array}$ & FFP2(31) & Standart sapma \\
\hline Yaş & 29 & 7,4 & 30 & 8,9 \\
Cinsiyet(Kadın/Erkek=n) & $62 / 19$ & & $16 / 15$ & \\
Alerji & 18 & & 3 & \\
Gözlük & 34 & & 12 & \\
Sigara & 31 & 22 & \\
\hline
\end{tabular}


Gönüllülerin maske kullanmadan 0. dakikada oksijen satürasyonları (SO2) ve kalp atım sayıları parmak pulse oksimetre cihazı ile ölçülerek not edildi. Bu aşamada baş ağrısı, kulak ağrısı, yüz çevresi rahatsızlık hissi ve nefes darlığı bildiren gönüllüler çalışma dışı bırakıldı. Maske taktıktan sonra gönüllüler rutin çalışmalarına devam ettiler. Maske kullanımı devam ederken 60. dakikada oksijen satürasyonu ve kalp atım sayıları parmak pulse oksimetre cihazı ile tekrar ölçülerek not edildi. $\mathrm{Bu}$ aşamada gönüllülerin nefes darlığ 1 , anksiyete veya huzursuzluk hissi, yüzde rahatsızlık hissi veya ağrı, kulakta ağrı ve görme problemi yaşayıp yaşamadıkları sorgulandı ve not edildi. Maske kullanımı devam ederken 180. dakikada gönüllülerin ölçümleri tekrarlandı ve şikâyetleri tekrar sorgulandi. 60. dakika veya 180. dakikada tıbbi işlemi devam etmesi nedeniyle ölçümü yapılamayan gönüllüler çalışma dışı bırakıldı. Tüm prosedürler, 2000 yılında revize edildiği üzere, insan deneyleri konusunda sorumlu komitenin etik standartlarına ve 1975 tarihli Helsinki Bildirgesine uygun olarak gerçekleştirilmiştir. (Etik Kurul Onayı, karar sayı numarası: İzmir Ekonomi Üniversitesi Etik Kurulu, B.30.2.İEÜSB.0.05.05-20-082)

\section{İstatistiksel analiz}

Verilerin analizinde SPSS 17 paket program kullanıldı. Gönüllüler FFP2 kullananlar ve geleneksel cerrahi maske kullananlar olarak iki gruba ayrıldı. Elde edilen verilerin dağılım analizi Kruskal Wallis ve Shapiro Wilk testleri ile incelendi. Verilerin normal dağılım gösterdiği görüldü ve ortalama \pm standart sapma olarak, FFP2 ve cerrahi maske kullanan gruplar arasında başlangıç, 60 ve 180. dakika oksijen satürasyonu ve nabız değerleri açısından fark olup olmadığı Student-t testi ile karşılaştırıldı. Ayrıca deneklerin, her bir grubun kendi içinde başlangıç, 60 ve 180. dakikalarda oksijen satürasyonu ve nabız değerleri açısından fark olup olmadığı Student-t testi ile değerlendirildi. $\mathrm{p}<0.05$ istatistiksel olarak anlamlı kabul edildi. Nefes darlığ 1 , anksiyete veya huzursuzluk hissi, yüzde rahatsızlık hissi, baş ağrısı, kulakta ağrı ve görmede değişiklik açısından grupların kendi içinde ve gruplar arasında fark olup olmadığı Ki-Kare testi ile değerlendirildi. Başlangıç değerleri ile 180. dakikadaki satürasyon ve nabız değerleri arasında oluşan fark ile sigara, alerjik hastalık öyküsü ve gözlük kullanımı açısından ortalamalar karşılaştırılmış ve Student-t testi uygulanmıştır. Satürasyon ve nabız farkının oluşması açısından bağımsız ilişki saptanması amacıyla lineer regresyon analizi yapılmıştır.

\section{Sonuçlar}

Çalışmaya 78(\%70) kadın, 34(\%30) erkek gönüllü katıldı. Gönüllülerin yaş ortalaması 1. grupta $29 \pm 7,4,2$. grupta $30 \pm 8,9^{\prime}$ du. 1 . grupta katılimciların $\% 76,5,2$. grupta $\%$ 53,3’ü kadındı. 1 . gruptaki katılımciların 18 'inde $(\% 22,2)$, 2. gruptaki katılımc1ların 3'ünde $(\% 9,7)$ alerji mevcuttu 1. grupta $31(\% 38,2)$ katılımcı, 2. grupta $22(\% 70,1)$ katılımcı sigara kullanıyordu. Her iki grupta gözlük kullanım oranları benzerdi. 0. dakika SO2 düzeyleri ortalamas1 1. grupta 98,2 $\pm 1,05$, 2. grupta

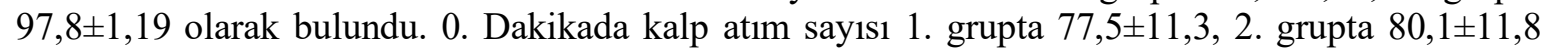

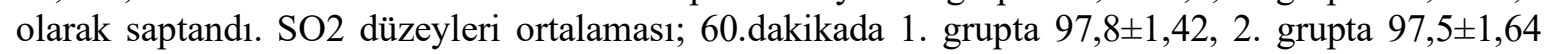

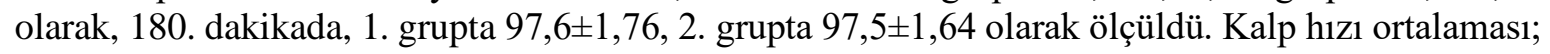

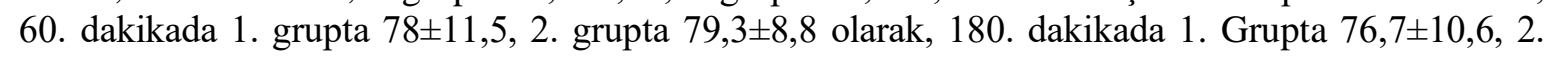
grupta 77,3 7,4 olarak ölçüldü (Şekil 1). Baş ağrısı 1. grupta 60. dakikada $14(\% 17,2), 180$. dakikada ise $24(\% 29,6)$ kat1limcida, 2. grupta ise 60.dakikada 5(\%16,1) 180 . dakikada ise $15(\% 48,3)$ katılımcıda görüldü. 1. grupta $22(\% 27,2)$ kişide 60 . dakikada, 32(\%39,5) kişide 180. dakikada, 2. grupta ise $14(\% 45,1)$ kişide 60 . dakikada, $20(\% 64,5)$ kişide 180 . dakikada yüzde rahatsızlık hissi mevcuttu. Kat1lımcıların 1. grupta 24'ünde (\%29,6) 60.dakikada, 32'sinde $(\% 39,5)$ 180.dakikada, 2. grupta ise 13'ünde $(\% 41,9) 60$ dakikada, 16'sında $(\% 51,6)$ 180. dakikada kulak ağrısı geliştiği görüldü. 1. gruptan $2(\% 2,5)$ gönüllü 60 . dakikada görmede değişiklik hissettiğini tarifledi, 180.dakikada $8(\% 9,9)$ gönüllüde benzer şikâyetler mevcuttu, 2 . gruptan ise $1(\% 3,2)$ gönüllü 60.dakikada, $7(\% 22,6)$ gönüllü 180 . dakikada benzer şikâyetler tarifledi. Çalışmaya katılan gönüllülerin 1. grupta 23’ü $(\% 28,4) 60$. dakikada anksiyete benzeri şikâyet bildirdi, bu grupta 180 . 
dakikada $34(\% 41,9)$ gönüllüde benzer durum mevcuttu, 2. grupta ise bu şikâyet 60 . dakikada 12 $(\% 38,7)$ gönüllüde, 180 . dakikada 18 (\%58) gönüllüde mevcuttu. Nefes darlı̆̆ l hissi ise; 1 . grupta 17 $(\% 20,9)$ kişide 60. dakikada, $26(\% 32)$ kişide 180 . dakikada bildirildi. 2. grupta ise $11(\% 35,4)$ kişide 60. dakika ve 18 (\%58) kişide 180. dakikada bildirildi. FFP2 kullanımının cerrahi maske kullanımıyla kıyaslandığında, 60. dakikada görülen baş ağrısı dışında tüm ölçümlerde kullanımda orantısal olarak daha fazla şikâyete yol açtığı görülmüştür. Ancak bu farklardan yalnızca 180. dakikada görülen yüzde rahatsızlık hissi ve nefes darlığı; istatiksel açıdan anlamlı bulunmuştur( $\mathrm{p}=0.020, \mathrm{p}=0.018$ )(Tablo 2$)$.

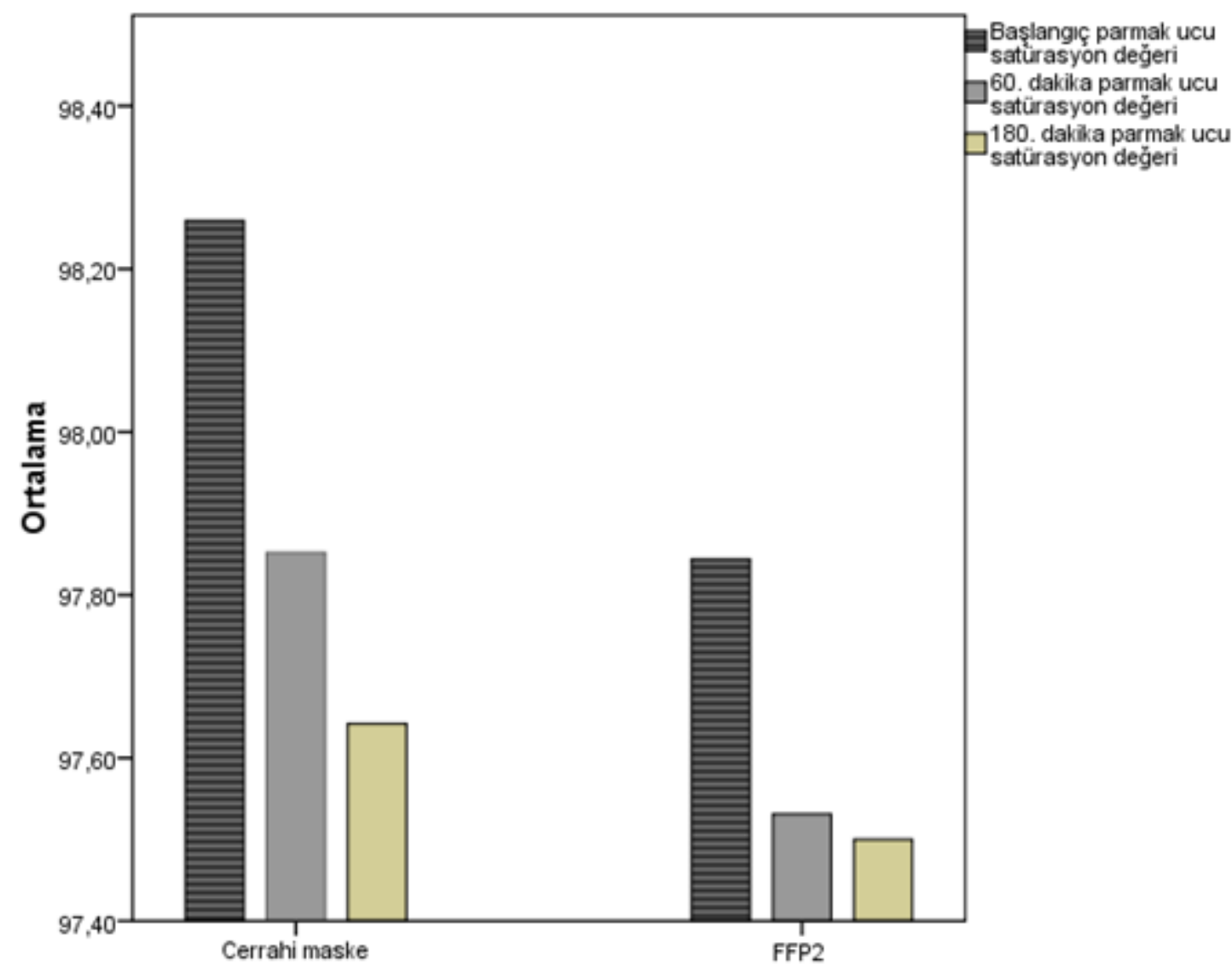

Şekil 1. Oksijen Satürasyonlarının Maskelere Göre Değişimi

Hem cerrahi maske hem de FFP2 maske takan grupta başlangıç ile 60. dakika $(p<0.001)$ ve 180. dakika $(\mathrm{p}<0.001)$, oksijen satürasyonları açısından istatistiksel anlamlı fark bulunmuştur. Yine başlangıç nabız değerleri ile 60 . dakika $(p<0.001)$ ve 180 . dakika nabız değerleri açısından $(p<0.001)$ istatistiksel anlamlı fark bulunmuştur.

Sigara kullanan ile kullanmayan grup arasında başlangıç satürasyon değerleri ile 180.dakika satürasyon $(p=0.352)$ ve nabız $(p=0.552)$ değerleri arasındaki fark istatistiksel açıdan anlamlı bulunmamıştır. Alerjik hastalık varlığı ve yokluğu arasında, başlangıç satürasyon değerleri ile 180.dakika satürasyon $(\mathrm{p}=0.296)$ ve nabız $(\mathrm{p}=0.549)$ değerleri üzerine etkisi fark istatistiksel açıdan anlamlı bulunmamıştır. Gözlük kullananlar ve kullanmayanlar arasında; başlangıç ölçüm değerleri ile 180.dakika satürasyon $(\mathrm{p}=0.400)$ ve nabız $(\mathrm{p}=0.725)$ değerleri arasındaki değişiklik açısından istatistiksel fark bulunmamıştır.

Lineer regresyon analizinde başlangıç satürasyon değerleri ile 180. dakika satürasyon değeri arasındaki fark ile maske türü, alerji varlı̆̆ı, gözlük kullanımı, sigara kullanımı, yaş ve cinsiyet 
arasında istatistiksel anlamlı ilişki saptanmamıştır. Çalışmaya dahil edilen ve ölçümleri yapılan kişilerden, rahatsızlık hissiyle maskesini 180 dakikadan önce sonlandıran kimse olmamıştır (Tablo 2).

Tablo 2: Oksijen Satürasyonu, Kalp Atım Hızı ve Şikâyetlerin 60. ve 180. Dakikalardaki Değişimi

\begin{tabular}{llllll}
\hline & $\begin{array}{l}\text { Cerrahi } \\
\text { maske(81) }\end{array}$ & $\begin{array}{l}\text { Standart } \\
\text { sapma }\end{array}$ & FFP2(31) & $\begin{array}{l}\text { Standart } \\
\text { sapma }\end{array}$ & $\mathrm{p}$ \\
\hline SO2 başlangıç & & & & & \\
SO2 60. dakika & 98,2 & $\pm 1,05$ & 97,8 & $\pm 1,19$ & 0,073 \\
SO2 180. dakika & 97,8 & 1,42 & 97,5 & 1,64 & 0,305 \\
Kalp atım hızı başlangıç & 97,6 & 1,76 & 97,5 & 1,64 & 0,696 \\
Kalp atım hızı 60. dakika & 77,5 & 11,3 & 80,1 & 11,8 & 0,278 \\
Kalp atım hızı 180. dakika & 78,0 & 11,5 & 79,3 & 8,8 & 0,575 \\
Baş ağrısı 60. dakika & 76,7 & 10,6 & 77,3 & 7,4 & 0,745 \\
Baş ağrısı 180. dakika & 14 & & 5 & & 0,832 \\
Yüzde rahatsılık 60. dakika & 24 & & 15 & & 0,082 \\
Yüzde rahatsızlık 180. dakika & 22 & & 14 & & 0,088 \\
Kulak ağrısı 60. dakika & 32 & & 20 & & 0,020 \\
Kulak ağrıs1 180. dakika & 24 & & 13 & & 0,262 \\
Nefes darlığı 60. dakika & 32 & & 16 & & 0,309 \\
Nefes darlığı 180. dakika & 17 & & 11 & & 0,138 \\
Görmede bozulma 60. dakika & 26 & & 18 & & 0,018 \\
Görmede bozulma 180. dakika & 8 & & 1 & & 0,845 \\
Anksiyete 60. dakika & 23 & & 7 & & 0,090 \\
Anksiyete 180. dakika & 34 & & 12 & & 0,170 \\
\hline
\end{tabular}

SO2: Oksijen Satürasyonu

\section{Tartışma}

Maske kullanımıyla ilgili bilimsel geçerliliği kabul gören ilk çalışmalar 20. Yüzyılın başlarına dayanmaktadır (Belkin,2009:883-891). Çalışmalarda; sağlık çalışanlarının salgın hastalıklardan korunmak için maske kullanmasının gerekliliği ve cerrahi esnasında cerrahi ekip tarafından maske kullanımının, cerrahi saha enfeksiyonlarını azalttığı bilimsel olarak kanıtlandıktan sonra, maske kullanımı sağlık çalışanları arasında yaygınlaşmıştır. İlerleyen dönemlerde cerrahi tıbbi maskelerin koruyuculuğu geliştirilmiş ve bu maskelere bazı standartlar getirilmiştir.

Maske günümüzde sağlık çalışanları tarafından, cerrahi sahayı korumak için tüm cerrahi girişimlerde, saha kontaminasyonu riski taşıyan invaziv girişimlerde, steril sahalarda yapılan çalışmalarda; çalışanların kendilerini korumak amacıyla da damlacık ve temas yoluyla bulaş ihtimali olan muayene ve işlemlerde kullanılmaktadır. COVID-19 pandemisi sürecinde sağlık çalışanlarının maske ihtiyacı artmıştır. Toplumun günlük yaşamda maske kullanımının gerekliliği de bu dönemde çok tartışılmıştır (Chan vd.,2020). Bu konuda; maskenin toplumda yaygın kullanımının hijyen kurallarına destek olacağı ve toplumda hasta olduğunu bilmeyen kişilerin damlacık yoluyla hastalık yaymasının engellenmesinde katkısı olabileceğini savunan yayınlar vardır (MacIntyre vd., 2009:233241; Cowling vd.,2009;151:437-446; Lau vd., 2008:434-443,). ECD 8.Nisan.2020'de yaptığ1 açıklamada; toplumda maske kullanımının hastalığın yayılımına etkisi net olarak bilinememekle beraber, kalabalık ortamlarda maske kullanımının düşünülebileceğini açıklamıştır. Buna karşın, 
maskenin toplumda yaygın kullanımının sağlık çalışanları için maske temininde güçlük oluşturabileceğini öne süren görüşler de mevcuttur (Feng vd.,2020:434-436).

Bu tartışmaların dışında medyada ve sosyal medyada bilimsel temelleri olmamasına karşın toplumda maske kullanılmasını önermeyen bazı paylaşımlar yapılmaktadır. Bu paylaşımların bazılarında maske kullanımının zararlı olduğu sonuçlarına varanlar dahi mevcuttur. Bu görüşe temel olarak bazı kişiler maskenin solunum kapasitesini düşürdüğünü öne sürmektedir. Toplumda da maske kullanımının güç bulunduğu görülmektedir. Maske kullanımı esnasında yaşanan sıkıntılar arasında nefes darlığ 1 ve huzursuzluk hissi başta sayılmaktadır. Biz çalışmamızda COVID-19 pandemisi sürecinde, düzenli maske kullanılan hastanemizin sağlık çalışanlarında, maskenin bazı çevrelerce belirtilen güçlüklerinin mevcut olup olmadığı ve düzenli maske kullanımının oksijen satürasyonu seviyesi ve kalp atım sayısına etkisini incelemek istedik.

FFP tipi maskelerin uzun süreli kullanımının tolere edilmesindeki güçlükler nedeniyle, bu maskelerin kullanımın sıkıntılarına ilişkin çok fazla çalışma yapılamamıştır (Bein vd., 2020). COVID-19 pandemisinde virülansın farklılı̆̆ nedeniyle, önceki pandemilere kıyasla bulaş ihtimalinin daha fazla olduğu düşünülmektedir. Bu yüzden bu süreçte diğer koruyucu önlemler artırıldığı gibi, maske kullanımı da yaygınlaşmıştır. Pandemi sürecinde hastanemizde, belli durumlarda FFP kullanımı zorunlu olduğu için, FFP kullanım süreleri uzamaktadır. Biz pandemi sürecinde çalışmamızda, uzamış zorunlu kullanım süreleri içinde FFP tipi maskelerde yaşanılan güçlükleri değerlendirebildik.

FFP2 tipi maskeler aerosollerin en az \%95'ini filtreleme özelliğine sahip maskelerdir. $\mathrm{Bu}$ koruyucu ölçü sebebiyle özellikle aerosol bulaşı riski taşıdığı için sağlık çalışanları tarafından kullanımı önerilmektedir. FFP maskelerin kullanımında inhalasyon ve ekshalasyon güçlükleri yaşanmaktadır. Ekshalasyonla ilgili sorunları çözmek için bu maskelere valfler eklenmektedir (Lee vd., 2008). FFP tipi maskelerin kullanım güçlükleri farklı çalışmalarda raporlanmıştır. Lepetellier ve ark. tarafindan yapılan çalışmada FFP maskelerin kullanımında solunum sıkıntıları ve rahatsızlık hissi olduğu vurgulanmıştır (Lepelletier vd., 2020). Biz çalışmamızda her iki maske tipinde de 60 . dakikada nefes darlığ 1 ve yüzde rahatsızlık hissedildiğini saptadık. İki sıkıntı da FFP2 tipi maske kullananlarda orantısal olarak daha fazla görüldü. 180 dakika kullanım sonrası her iki grupta etkilenen kişi sayısında artış saptandı. Her iki şikâyetin; FFP2 tipi maske kullanımında, cerrahi maskeyle kıyaslandığında istatistiksel anlamlı fazla olduğu görüldü. İki grupta da oksijen satürasyonlarında 60. ve 180. dakikada düşüş görüldü. Ancak fizyolojik sınırların dışında değere rastlanmadi.

Cerrahi maske ve FFP2 kullanımının alerjiye yol açtı̆̆ını belirten çalışmalar mevcuttur. Navarro-Triviño ve ark. yayınladıkları olgu sunumunda, daha önce alerjik hastalık öyküsü olmayan bir hastane çalışanında, FFP2 maske kullanımı sonrası kontakt dermatit gelişimini incelemişlerdir (Navarro-Triviño vd., 2020). Başka bir çalışmada sağlık çalışanlarında N95 maske kullanımıyla ilişkili cilt reaksiyonları değerlendirilmiştir (Al Badri, 2017). Biz çalışmamızda gönüllüler arasında alerji mevcudiyetini sorguladık. Daha önceden alerjik hastalık öyküsü olan gönüllülerde şikâyetlerin, alerjik hastalık olmayanlarla farkını inceledik. Hiçbir hastamızda 180 dakika kullanım esnasında alerjik reaksiyon gözlemlemedik. Alerjik hastalık tanısı mevcut gönüllülerle, alerjik hastalığı olmayan gönüllüler arasında 60 ve 180. dakikada, kalp atımı hızı ve SO2 değerlerindeki değişiklik açısından her iki maske grubunda da istatistiksel anlamlı fark saptanmadı.

Maske kullanımıyla ilgili dile getirilen bir diğer sık şikâyet yüzde rahatsızlık hissidir. Yüzde ağrı, huzursuzluk hissi ve basılar başlıca şikâyetler arasındadır. Bu şikâyetleri azaltmak için maskelerde bazı düzenlemeler önerilmektedir. Field ve ark. yaptıkları çalışmada FFP tipi maske kullanımı sonrası yüzde ve burunda meydana gelen ağrı ve basınç hissini azaltmak için burun üstüne strip yapıştırılmasını önermişlerdir (Field vd., 2020). 2020'de yapılan bir başka çalışmada; FFP tipi maskelerin etkinliğini artırırken kullanım güçlüğünü azaltmak için, 3 boyutlu baskı yardımıyla kişiye 
özel maske yapımı önerilmektedir (Swennen vd., 2020). Biz çalışmamızda, cerrahi maske kullanan gönüllülerin 60. dakikada $\% 27,2$ 'sinde, 180 . dakikada $\%$ 39,5'inde yüzde rahatsızlık hissinin mevcut olduğunu, FFP2 maske kullanan gönüllerin ise 60. dakikada \%45,1'inde, 180. dakikada ise $\% 64,5$ 'inde yüzde rahatsızlık hissi mevcut olduğunu gördük. Bu şikâyetin her iki grupta da yüksek oranlarda mevcut olduğunu, FFP2 maske kullananlarda belirgin farklı olduğunu gördük.

Maske kullanırken görmeyle ilgili sıkıntılar da belirtilmektedir. Ayrıca gözlük kullananlarda maskeye bağlı ek sıkıntılar görülmektedir. Japonya'da yapılan bir çalışmada maske kullanımın güçlükleri incelendiğinde, maske nemlenmesi, gözlük kullanımı ile ilgili sıkıntılar ve nefes darlığ 1 incelenmiştir (Morishima ve Kishida, 2018). Biz çalışmamızda maske kullanımında 60. ve 180. dakikalarda görme değişikliğini değerlendirdik. Ayrıca gözlük kullananlarda şikâyetlerde artış olup olmadığını da değerlendirdik. Gözlük kullanımının vital bulgularda ek bir değişikliğe yol açmadığı görüldü. 60. dakikada görmeyle ilgili şikâyetler cerrahi maske grubunda 2 kişide, FFP2 grubunda ise yalnız 1 kişide görüldü. 180. dakikada bu sayılar sırasıyla 8 ve 7'ye yükseldi. Tarif edilen sıkıntılar arasında bulanıklık, net görememe ve göz arkasında ağnı bulunmaktaydı.

Cerrahi ve N95 tipi maskelerin kullanımının değerlendirildiği bir başka çalışmada azımsanmayacak oranda şikâyetler geliştiği belirtilmiştir (Zou vd,. 2020). Çalışmada şikâyetler; maske süresi göz önünde bulundurulmadan ve maske tipi ayırt edilmeksizin, genel kullanımda raporlanmıştır. Katılımcıların \%49'unda cilt reaksiyonu, \%17,1'inde solunum yollarıyla ilgili sorunlar ve \%6.2'sinde gözle ilgili bulgular bildirilmiştir. Bu seri fazla sayıda şikâyetlerin değerlendirildiği ender çalışmalardan biridir. Biz çalışmamızda bu şikâyetlere ek olarak, kulak ağrısı, baş ağrısı, anksiyeteyi de değerlendirdik.

Çalışmamızda, FFP2 maskelerin cerrahi maskelere kıyasla daha fazla şikâyete yol açtığı ve daha az tolere edildiği görülmektedir. Cerrahi maske kullananlarda 60. dakikada baş ağrıs1 istatistiksel anlamlı olmamakla beraber, orantısal olarak FFP2 maske kullananlara kıyasla daha fazla görülmektedir. 180. dakikada ise orantısal ilişki tersine dönmektedir. Kulak ağrısı, görme değişiklikleri, anksiyete, yüzde rahatsızlık hissi ve nefes darlığ1 şikâyetleri ise FFP2 maske kullananlarda hem 60. dakikada hem 180. dakikada daha fazla görülmüştür. Yüzde rahatsızlık hissi ve nefes darlığı açısından iki grup arasında istatistiksel anlamlı fark saptanmıştır.

Ölçümlerimizde; SO2 ve kalp atım hızı değerlerinin her iki maske tipinin kullanımında da 180. dakikada, düşme eğiliminde olduğu görülmüştür ve bu değişiklikler istatistiksel anlamlı bulunmuştur. Ancak birbirleriyle kıyaslandığında iki grup arasında, SO2 ve kalp atım hızı düşüşü açısından istatistiksel anlamlı fark görülmemiştir. Her iki maske grubunda sigara kullanımının, alerji varlığının ve gözlük kullanımın SO2 değerlerine ve kalp atım hızına etkileri değerlendirilmiştir. Bu değerlendirmelerde sigara kullanımı, alerji varlığının ve gözlük kullanımının SO2 ve kalp atım sayıSı üzerinde istatistiksel anlamlı etkilerinin olmadığı görülmüştür.

Biz ölçümlerimiz ve gönüllülerin şikâyetleri doğrultusunda; FFP2 maske kullanımının tolere edilmesi daha zor olmasına karşın 60 dakika ve 180 dakika kullanımda cerrahi maskeyle kıyaslandığında solunum ve kalp üzerine olumsuz bir etkisine rastlamadık. Her iki grupta da SO2 ve kalp atım hızının fizyolojik sınırları aşan bir değişimi hiçbir gönüllüde gözlenmedi. 180 dakika takibimiz esnasında gönüllülerden, subjektif yakınma ya da objektif ölçümlerle maske kullanımını sonlandırılmak zorunda kalan kimse olmadı.

Bulaşıcı hastalıkların önlenmesinde maskenin etkinliğiyle ilgili çalışmaların çoğu sağlık çalışanlarında etkinliğin değerlendirildiği çalışmalardır. Toplumda bulaşın değerlendirilmesi için yapılacak çalışmalar hem örneklem grubunun kontrolü, hem maskenin düzgün kullanımının kontrolü hem hastalığın yayılımının takibindeki güçlükler nedeniyle geniş seriler şeklinde yapılamamaktadır. Maske etkinliği üzerine yapılan derlemelerden çıkan sonuçlar doğrultusunda; toplum sağlığının korunmasında ek bir önlem olarak, özellikle damlacık yoluyla bulaşan hastalıklarda maskenin 
toplum tarafindan da kullanılması önerilmektedir (Javid vd., 2020; Davies vd., 2013; Eikenberry vd., 2020).

Maske sağlık çalışanlarına olduğu kadar, topluma da; el yıkama, sosyal mesafe gibi önlemlere ek bir önlem olarak önerilmektedir. Sağlık çalışanlarının aksine; toplumda günlük kullanımda hangi maskenin tercih edileceği henüz bilinmemektedir. FFP maskeler yaygın şekilde kullanılmaktadır. Ancak bu maskeler hem tolerasyonu zor hem de kullanım alanı açısından toplum için uygun değildir. Cerrahi tıbbi maske kullanımı yeterli olmaktadır. Bazı çevrelerce maske kullanımının sağlığa zararlı olduğu yönünde açıklamalar yapılmaktadır. Biz çalışmamızda; 1 ve 3 saatlik kullanımlarda azımsanmayacak sayıda rahatsızlıklar tariflense de solunum ve dolaşım sisteminin patolojik etkilendiği bir duruma rastlamadık ve toplumda cerrahi tıbbi maskenin kullanılmasının kişilerin kendilerini korumasına yardımcı olacağı ve maske kullanımının sağlığa zararlı olmadığg sonucuna vardık.

\section{Araştırmanın sınırlılıkları}

Çalışmamızın başlıca eksik yönleri az sayıda kişiyle yapılmış olması, FFP maske kullanan az kişi olması, maske kullanımının süre olarak çok uzun olmaması ve uzun takip yapılmamış olmasıdır. Bu alanda daha uzun takipli çalışmaların yapılması, kan gazı ölçümü gibi invaziv işlemlerle kanda oksijen satürasyonunun ölçülmesi daha doğru sonuçlar verecektir.

\section{Sonuç}

Literatürde maske kullanımının olumsuz etkilerini inceleyen çalışmalarda vital bulguların değerlendirildiği ve daha önce tanımlanmış sıkıntılarının tamamını değerlendiren bir çalışmaya rastlamadık. Çalışmamızın bu anlamda literatüre katkı sağlayacağını düşünmekteyiz. Toplum sağlığının korunmasında birçok önlem alınmaktadır. Bu önlemler uzun yıllar boyunca edinilen tecrübelerden ve farklı durumlardan yapılan uyarlamalardan elde edilmektedir. COVID-19 pandemisi sürecinde daha önceki pandemilerde ve bulaşıcı salgın hastalıklarda olduğu gibi, toplumun korunması hastalıkla mücadelenin ilk basamağıdır. Bu süreçte hem korunma hem tedavi prensipleri henüz netlik kazanmamıştır. Bu konulara açılık getirmek için birçok çalışma yürütülmektedir. Sağlıklı bireyler arasında önlemlerin değerlendirildiği çalışmaların toplumda geniş seriler şeklinde yürüttülmesi oldukça güçtür. Bu sebeple modellemeler ve özellikle önlemleri sık1 uygulamak zorunda kalan sağlık çalışanlarıyla yapılan çalışmalara baştadır. Eksiklikleri olmakla beraber, nispeten uzun kabul edilebilecek süre maske kullanan sağlık çalışanlarıyla yaptığımız çalışmamızın sonuçlarının, topluma uyarlanabileceği ve toplum sağlığı açısından yararlı olabileceğini düşünmekteyiz.

\section{Kaynakça}

Al Badri FM. Surgical mask contact dermatitis and epidemiology of contact dermatitis in healthcare workers. Current Allergy \& Clinical Immunology. 2017;30(3):183-188

Bakioğlu, B., Çevik, M. (2020). COVID-19 pandemisi sürecinde fen bilimleri öğretmenlerinin uzaktan eğitime ilişkin görüşleri. Turkish Studies, 15(4), 109-129. https://dx.doi.org/10.7827/TurkishStudies.43502

Bartoszko JJ, Farooqi MAM, Alhazzani W, Loeb M. (2020). Medical masks vs N95 respirators for preventing COVID-19 in healthcare workers: A systematic review and meta-analysis of randomized trials [published online ahead of print, 2020 Apr 4]. Influenza Other Respir Viruses, 10.1111/irv.12745. https://dx.doi.org/10.1111/irv.12745

Belkin NL. (2009). The surgical mask: are new tests relevant for OR practice?. AORN J, 89(5):883891. https://dx.doi.org/10.1016/j.aorn.2008.09.016 
Bein B, Bachmann M, Huggett S, Wegermann P. (2020). SARS-CoV-2/COVID-19: Empfehlungen zu Diagnostik und Therapie [SARS CoV-2/COVID-19: Evidence-Based Recommendation on Diagnosis and Therapy]. Anasthesiol Intensivmed Notfallmed Schmerzther, 55(4):257265. https://dx.doi.org/10.1055/a-1146-8674

CDC. (2020). Interim Infection Prevention and Control Recommendations for Patients with Suspected or Confirmed Coronavirus Disease 2019 (COVID-19) in Healthcare Settings. https://www.cdc.gov/coronavirus/2019-ncov/infection-control/controlrecommendations.html (Update 19.JUNE.2020)

Chan JF, Yuan S, Kok KH, To KK, Chu H, Yang J, Xing F, Liu J, Yip CC, Poon RW, Tsoi HW, Lo SK, Chan KH, Poon VK, Chan WM, Ip JD, Cai JP, Cheng VC, Chen H, Hui CK, Yuen KY. (2020). A familial cluster of pneumonia associated with the 2019 novel coronavirus indicating person-to-person transmission: a study of a family cluster. Lancet, 395:514 -523. https://dx.doi.org/10.1016/S0140-6736(20)30154-9

Chan JF, Zhang AJ, Yuan S, et al. (2020). Simulation of the clinical and pathological manifestations of Coronavirus Disease 2019 (COVID-19) in golden Syrian hamster model: implications for disease pathogenesis and transmissibility [published online ahead of print, 2020 Mar 26]. Clin Infect Dis, ciaa325. https://dx.doi.org/10.1093/cid/ciaa325

Chan KH, Yuen KY. (2020). COVID-19 epidemic: disentangling the re-emerging controversy about medical facemasks from an epidemiological perspective [published online ahead of print, 2020 Mar 31]. Int J Epidemiol. 2020;dyaa044. https://dx.doi.org/10.1093/ije/dyaa044

Chen N, Zhou M, Dong X, et al. (2020). Epidemiological and clinical characteristics of 99 cases of 2019 novel coronavirus pneumonia in Wuhan, China: a descriptive study. Lancet, 395(10223):507-513. https://dx.doi.org/10.1016/S0140-6736(20)30211-7

Cheng VC, Lau SK, Woo PC, Yuen KY.( 2007). Severe acute respiratory syndrome coronavirus as an agent of emerging and reemerging infection. Clin Microbiol Rev, 20:660-94.

Cheng VC, To KK, Tse H, Hung IF, Yuen KY. ( 2012). Two years after pandemic influenza A/2009/H1N1: what have we learned? Clin Microbiol Rev, 25:223-63.

Cheng VC, Wong SC, Chuang VW, et al. (2020). The role of community-wide wearing of face mask for control of coronavirus disease 2019 (COVID-19) epidemic due to SARS-CoV-2 [published online ahead of print, 2020 Apr 23]. J Infect, S0163-4453(20)30235-8. https://dx.doi.org/10.1016/j.jinf.2020.04.024

Corman VM, Landt O, Kaiser M, Molenkamp R, Meijer A, Chu DK, Bleicker T, Brünink S, Schneider J, Schmidt ML, Mulders DG, Haagmans BL, van der Veer B, van en Brink S, Wijsman L, Goderski G, Romette JL, Ellis J, Zambon M, Peiris M, Goossens H, Reusken C, Koopmans MP, Drosten C. (2020). Detection of 2019 novel coronavirus (2019-nCoV) by real-time RT-PCR. Euro Surveill, 25(3):pii2000045. https://dx.doi.org/10.2807/1560 7917.ES.2020.25.3.2000045

Cowling BJ, Chan KH, Fang VJ, Cheng CK, Fung RO, Wai W, et al. (2009). Facemasks and hand hygiene to prevent influenza transmission in households: a cluster randomized trial. Ann Intern Med, 151:437-46.

ECDC. (2020). Infection prevention and control for COVID-19 in healthcare settings. Technical report 13.May.2020. https://www.ecdc.europa.eu/en/publications-data/infection-preventionand-control-covid-19-healthcare-settings 
Feng S, Shen C, Xia N, Song W, Fan M, Cowling BJ. (2020). Rational use of face masks in the COVID-19 pandemic. Lancet Respir Med, 8(5):434-436. https://dx.doi.org/10.1016/S22132600(20)30134-X

Field MH, Rashbrook JP, Rodrigues JN. (2020). Hydrocolloid dressing strip over bridge of nose to relieve pain and pressure from Filtered Face Piece (FFP) masks during the coronavirus (COVID-19) pandemic. Ann R Coll Surg Engl, 102(5):394-396. https://dx.doi.org/10.1308/rcsann.2020.0095

Guan WJ, Ni ZY, Hu Y, Laing WH, Ou CQ, He JX, et al. (2020). Clinical characteristics of 2019 novel coronavirus infection in China. medRxiv, Feb 9. https://dx.doi.org/10.1101/ 2020.02.06.20020974

Hui DS, Chow BK, Chu L, et al. (2012). Exhaled air dispersion during coughing with and without wearing a surgical or N95 mask. PLoS One, 7(12):e50845. https://dx.doi.org/10.1371/journal.pone.0050845

Hirschmann MT, Hart A, Henckel J, Sadoghi P, Seil R, Mouton C. (2020). COVID-19 coronavirus: recommended personal protective equipment for the orthopaedic and trauma surgeon [published correction appears in Knee Surg Sports Traumatol Arthrosc. 2020 Jun 12;:]. Knee Surg Sports Traumatol Arthrosc, 28(6):1690-1698. https://dx.doi.org/10.1007/s00167-02006022-4

Lau JT, Kim JH, Tsui HY, Griffiths S. (2008). Perceptions related to bird-to-human avian İnfluenza, influenza vaccination, and use of face mask. Infection, 36(5):434-443. https://dx.doi.org/10.1007/s15010-008-7277-y

Lee SA, Grinshpun SA, Reponen T. (2008). Respiratory performance offered by N95 respirators and surgical masks: human subject evaluation with $\mathrm{NaCl}$ aerosol representing bacterial and viral particle size range. Ann Occup Hyg, 52(3):177-185. https://dx.doi.org/10.1093/annhyg/men005

Lepelletier D, Grandbastien B, Romano-Bertrand S, et al.(2020). What face mask for what use in the context of COVID-19 pandemic? The French guidelines [published online ahead of print, 2020 Apr 26]. J Hosp Infec, S0195-6701(20)30211-5. https://dx.doi.org/10.1016/j.jhin.2020.04.036

Leung CC, Lam TH, Cheng KK. (2020). Mass masking in the COVID-19 epidemic: people need guidance. Lancet, 21;395(10228):945.

MacIntyre CR, Cauchemez S, Dwyer DE, Seale H, Cheung P, Browne G, et al. (2009). Face mask use and control of respiratory virus transmission in households. Emerg Infect Dis, 15:23341.

MacIntyre CR, Wang Q, Seale H, et al. (2013). A randomized clinical trial of three options for N95 respirators and medical masks in health workers. Am J Respir Crit Care Med, 187(9):960966. https://dx.doi.org/10.1164/rccm.201207-1164OC

Ma QX, Shan H, Zhang HL, Li GM, Yang RM, Chen JM. (2020). Potential utilities of mask-wearing and instant hand hygiene for fighting SARS-CoV-2 [published online ahead of print, 2020 Mar 31]. J Med Virol, 10.1002/jmv.25805. https://dx.doi.org/10.1002/jmv.25805

Morishima M, Kishida K. (2018). Understanding attitudes toward hygiene mask use in Japanese daily life by using a repeated cross-sectional survey. Work, 61(2):303-311. https://dx.doi.org/10.3233/WOR-182801 
Navarro-Triviño FJ, Merida-Fernández C, Ródenas-Herranz T, Ruiz-Villaverde R. (2020). Allergic contact dermatitis caused by elastic bands from FFP2 mask [published online ahead of print, 2020 May 13]. Contact Dermatitis,10.1111/cod.13600. https://dx.doi.org/10.1111/cod.13600

Sun P, Lu X, Xu C, Sun W, Pan B. (2020). Understanding of COVID-19 based on current evidence. J Med Virol, 92:jmv.25722. https://dx.doi.org/10.1002/jmv.25722

WHO.(2020). Modes of transmission of virüs causing COVID-19:implications for IPC precaution recommendations. Scientific brief 29 March 2020. available at https://www.who.int/newsroom/commentaries/detail/modes-of-transmission-of-virus-causing-covid-19-implicationsfor-ipc-precaution-recommendations

Zan, N., Zan, B. U. (2020). Koronavirüs ile acil durumda eğitim: Türkiye'nin farklı bölgelerinden uzaktan eğitim sistemine dahil olan Edebiyat Fakültesi öğrencilerine genel bakış. Turkish Studies, 15(4), 1367-1394. https://dx.doi.org/10.7827/TurkishStudies.44365

Zhai Z. (2020). Facial mask: A necessity to beat COVID-19. Build Environ, 175: 106827. https://dx.doi.org/10.1016/j.buildenv.2020.106827

Zhou P, Yang XL, Wang XG, et al. (2020). A pneumonia outbreak associated with a new coronavirus of probable bat origin. Nature,579(7798):270-273. https://dx.doi.org/10.1038/s41586-0202012-7

Zhu N, Zhang D, Wang W, Li X, Yang B, Song J, Zhao X, Huang B, Shi W, Lu R, Niu P, Zhan F, Ma X, Wang D, Xu W, Wu G, Gao GF, Tan W, China Novel Coronavirus Investigating and Research Team. (2020). A novel coronavirus from patients with pneumonia in China, 2019. N Engl J Med, 382:727-733. https://dx.doi.org/10.1056/NEJMoa2001017

Zuo Y, Hua W, Luo Y, Li L. (2020). Skin reactions of N95 masks and medial masks among health care personnel: a self-report questionnaire survey in China. Contact Dermatitis. [published online ahead of print, 2020 Apr 16]. https://dx.doi.org/10.1111/cod.13555 